\title{
Školski uspjeh djece i mladih koji odrastaju u siromaštvu i materijalno nepovoljnim uvjetima
}

Vesna Bilić*

vesna.bilic@ufzg.hr
UDK: $364.65: 371.26$

371.26:364.65

Pregledni članak / Review

Primljeno: 18. siječnja 2016.

Prihvaćeno: 29. veljače 2016.

Budući da je siromaštvom pogođen sve veći broj djece i mladih nužno je ukazivati i na njegove moguće doprinose njihovim školskim i životnim ishodima. Stoga se u ovom radu, na temelju literature, analiziraju čimbenici rizika i procesi koji objašnjavaju kako odrastanje u siromaštvu i materijalnoj oskudici izravno $i$ neizravno utječe na školski uspjeh i obrazovne ishode djece. Ukazuje se na štetne učinke u ranom razdoblju života djece, a koje je presudno za formiranje vještina i sposobnosti važnih za školsko postignuće. Višestruki nedostaci s kojim započinju školovanje ugrožavaju njihovo napredovanje i postizanje uspjeha na svim razinama obrazovanja (ranom, školskom i visokoškolskom). A kombinacija siromaštva i slabijeg školskog uspjeha, često je razlog za napuštanje škole ili završavanje nižeg stupanja obrazovanja, a povezuju se i sa slabijim šansama za zaposlenje is težim izlaskom iz kruga siromaštva. Zaključno se iznose prijedlozi za razvoj strategija, ranih $i$ kasnih intervencija te osiguravanje višestruke podrške obitelji i pomoći djeci u realizaciji njihovih potencijala, te postizanju školskih $i$ životnih uspjeha.

Ključne riječi: siromaštvo, socioekonomski status (SES), materijalna deprivacija, školski uspjeh.

\footnotetext{
* Izv. prof. dr. sc. Vesna Bilić, Katedra za pedagogiju Učiteljskoga fakulteta Sveučilišta u Zagrebu, Savska 77, HR-10000 Zagreb.
} 


\section{Uvod}

U vremenu i kulturi kad se materijalne vrijednosti uzdižu na pijedestal i postaju cilj kojem mnogi teže, uspjeh u školi se percipira kao prvi korak koji pruža pojedincu veće šanse za ostvarenje tog cilja, kvalitetniji život i blagostanje.

Najčešće se pod uspjehom misli na prosječan školski uspjeh izražen kvantitativno (učenici i roditelji priželjkuju 5,0), a pri tome se često zanemaruje kvaliteta znanja i razvoj dječjih potencijala. Na školski uspjeh, odnosno neuspjeh, utječe niz čimbenika (individualnih, obiteljskih, školskih, društvenih) u različitom suodnosu. ${ }^{1}$ A u brojnim istraživanjima je utvrđeno da odrastanje u materijalno nepovoljnim uvjetima negativno utječe na školski uspjeh djece. ${ }^{2}$ Iako rezultati ovih istraživanja ostavljaju malo prostora za sumnju, otvaraju pitanja procesa ili mehanizama na koji se taj utjecaj ostvaruje. Budući da je siromaštvom pogođen sve veći broj djece, nužno je ukazivati i na njegove moguće doprinose njihovim školskim i životnim ishodima.

Velika ekonomska i društvena kriza, nestabilnost na tržištu rada, koja je obilježila početak 21. stoljeća uzrokovala je porast siromaštva. Sve veći broj ljudi živi u apsolutnom siromaštvu, odnosno nemaju osigurane elementarne uvjete za život, dovoljnu količinu hrane, adekvatno grijanje, odjeću i stanovanja, a primanja su im manja od $30 \%$ medijana nacionalnog dohotka. ${ }^{3}$ Povećava se i broj onih koji nemaju minimalno pristojan životni standard koji je uobičajen $u$ zajednici ili društvu u kojem žive, a primanja su im manja od 60 \% medijana nacionalnog dohotka (relativno siromaštvo). Ovim dvjema skupinama koje se tradicionalno definiraju kao siromasi pridružuju se i oni koji su donedavna živjeli relativno zbrinuto i sigurno, a koje se naziva novim siromasima. ${ }^{4}$ Naime, velik broj njih je ostao bez posla, dio ih radi, ali ne dobivaju plaću ili ne zarađuju dovoljno da bi osigurali pristojne životne uvjete na kakve su navikli, a ne mogu vraćati ni ranije olako uzete stambene kredite ni plaćati režije. Gubitak posla, nemogućnost da pronađu novi posao ili slaba primanja uz prezaduženost doveli su ih do ruba siromaštva, suočavaju se s deložacijama i ovrhama i sl. ${ }^{5}$

Opisane situacije najviše pogađaju najranjivije skupine, a to su svakako djeca. Prema podacima UN-a i Svjetske banke danas u svijetu od posljedica siro-

\footnotetext{
${ }^{1}$ Usp. V. BILIĆ, Uzroci, posljedice i prevladavanje školskog neuspjeha, Zagreb, HPKZ, 2001.

${ }^{2}$ Usp. H. B. FERGUSON, S. BOVAIRD, M. P. MÜLLER, The impact of poverty on educational outcomes for children, Journal of Paediatrics and Child Health, 12 (2007) 8, 701-706; S. McCOY, D. BYRNE, B. JOANNE, Too Much of a Good Thing? Gender, 'Concerted Cultivation' and Unequal Achievement in Primary Education, Child Indicators Research, 5 (2012) 1, 155178; C. RATCLIFFE, Child Poverty and Adult Success. Low Income Working Families brief, Washington, DC, Urban Institute, 2015.

${ }^{3}$ Usp. Z. ŠUĆUR, Stari i novi siromasi u hrvatskom društvu. Empirijski uvid, Bogoslovska smotra, 84 (2014) 3, 577-610.

${ }^{4}$ Usp. isto.

${ }^{5}$ Usp. isto.
} 
maštva svakog dana umre 29.000 djece u dobi do pet godina. ${ }^{6}$ U Hrvatskoj je do 2010. godine 14 do $18 \%$ djece predškolske dobi živjelo ispod praga siromaštva, ${ }^{7}$ a ukupno je u dvije godine broj siromašne djece porastao za $4000{ }^{8}$

Kad se govori o siromaštvu odraslih obično se misli na prinudni nedostatak financijskih sredstava, ali dječje siromaštvo (engl. child poverty) uz to uključuje i nemogućnost pristupa resursima i aktivnostima, ${ }^{9}$ kao i njihov subjektivan doživljaj takvog stanja. Nedostatak materijalnih sredstava otežava roditeljima da djeci osiguraju adekvatnu odjeću, obuću, topli obrok, knjige i pribor za školu, ali i pristup dodatnim aktivnostima (učenje stranog jezika, instrukcije, sport i sl.), a ograničene su im i mogućnosti druženja s vršnjacima u slobodno vrijeme (razredni izleti, izlasci, proslave). Dakle, roditelji im nisu u mogućnosti ispuniti materijalne i nematerijalne potrebe, pa oni, osobito u školi, doživljavaju višestruku deprivaciju. ${ }^{10}$ Siromaštvo se djece opisuje kao odsutnost bilo kojeg od ovih činitelja: a) ako dijete odrasta bez adekvatnih sredstava za život (financijskih i nutritivnih resursa); b) bez mogućnosti za ljudski razvoj što uključuje pristup obrazovanju i razvoju vještina te zdravstvenoj skrbi. ${ }^{11}$ Neki autori upozoravaju da se ne smije podcijeniti utjecaj materijalne neimaštine različitih stupnjeva. ${ }^{12}$ Stoga ćemo u ovu analizu uz siromašne, uključiti i skupine djece koja odrastaju u materijalno nepovoljnim uvjetima.

Odrastanje u siromaštvu povezuje se $\mathrm{s}$ mnogim negativnim ishodima, ponajprije sa zdravstvenim i ponašajnim problema, ${ }^{13}$ te lošijim školskim uspjehom i ishodima obrazovanja. Posljedice su ozbiljnije ako a) dijete živi u ekstremnom siromaštvu, iako i kratka razdoblja deprivacije mogu ostaviti dugoročne posljedice $;^{14}$ b) smatra se da dugotrajna izloženost snažnije negativno utječe na razvojne i obrazovne ishode ${ }^{15}$ odnosno da je štetnije uporno siromaštvo nego prolazno; c) osobito je štetan doživljaj siromaštva u ranom djetinjstvu. ${ }^{16}$

${ }^{6}$ Usp. B. ZEBIĆ, Globalna pravednost i siromaštvo u svijetu u interpretaciji Thomasa Poggea, Obnovljeni život, 67 (2012) 4, 511-526.

7 Usp. Z. ŠUĆUR i dr., Siromaštvo i dobrobit djece predškolske dobi u Republici Hrvatskoj, Zagreb, Ured UNICEF-a za Hrvatsku, 2015.

8 Usp. Strategija borbe protiv siromaštva i socijalne isključenosti u Republici Hrvatskoj (20142020), (02.04.2014) www.mspm.hr/djelokrug_aktivnosti/socijalna_skrb/strategija_borbe_protiv_siromastva_i_socijalne_iskljucenosti_2014_2020 (17.01.2016).

${ }^{9}$ Usp. A. MINUJIN i dr., The definition of child poverty. A discussion of concepts and measurements, Environment and Urbanization, 18 (2006) 2, 481-500.

${ }^{10}$ Usp. C. DE NEUBOURG, I. M. DE MILliANO, Z. PLAVGO, Lost (in) Dimensions. Consolidating progress in multidimensional poverty research, Innocent Working Paper No. 2014-04, Florence, UNICEF Office of Research, 2014.

${ }^{11}$ Usp. Šućur i dr., nav. dj., 4.

${ }^{12}$ Usp. Ferguson, Bovaird, Müller, nav. dj.

${ }^{13}$ Usp. M. LACOUR, D. TISSINGTON, Review. The Effects of Poverty on Academic Achievement, Educational Research and Reviews, 6 (2011) 7, 522-527.

${ }^{14}$ Usp. Minujin i dr., nav. dj.

${ }^{15}$ Usp. I. SCHOON i dr., Family hardship and children's development. The early years, Longitudinal and Life Course Studies, 1 (2010) 3, 209-222.

${ }^{16}$ Usp. G. J. DUNCAN, A. KALIL, K. M. ZIOL-GUEST, Early childhood poverty and adult achie- 
U ovom radu siromaštvu i odrastanju u materijalno nepovoljnim uvjetima pristupa se kao mogućim čimbenicima rizika za postizanje uspjeha na raznim stupnjevima obrazovanja (ranom, školskom i visokoškolskom).

A cilj je rada na osnovu literature analizirati čimbenike, ali i procese koji objašnjavaju kako odrastanje u siromaštvu i materijalnoj oskudici utječe na školski uspjeh i obrazovne ishode djece i adolescenata.

Analiza čimbenika rizika i identificiranje potencijalno zaštitnih čimbenika jedan je od važnih koraka u borbi protiv dječjeg siromaštva. Polazimo od teze da neuspjeh nije fiksan, on se može mijenjati tijekom vremena, a sva djeca koja odrastaju u nepovoljnim uvjetima nisu neuspješna. Dapače, postoje brojni primjeri djece koja su, unatoč otežavajućim okolnostima, uspjela postići dobre rezultate u školi i uspjeti u životu. Budući da se problemi koje analiziramo povezuju i sa smanjenom kvalitetom roditeljstva, potrebno je i u ovom slučaju reći da se brojni siromašni roditelji, usprkos svim egzistencijalnim problemima i stresu, ponašaju na adekvatan način, s ljubavlju odgajaju i podižu svoju djecu, uspijevaju sačuvati i njegovati dobre obiteljske odnose i zaštititi ih od različitih nepovoljnih vanjskih utjecaja.

\section{Teorijski okvir za razumijevanje utjecaja siromaštva na školski uspjeh}

U objašnjenju procesa ili mehanizama kojim obiteljske materijalne poteškoće različitog stupnja utječu na djecu pristupa se iz različitih perspektiva, ekonomske, socijalno- psihološke i sl.

Jedan od poznatijih ekonomskih pristupa je obiteljski investicijski model, ${ }^{17}$ prema kojem bolji obiteljski materijalni resursi te ljudski (znanje i vještine) i socijalni kapital (status, moć, veze) impliciraju više ulaganje u razvoj djece, a što se povezuje s pozitivnim razvojnim ishodima i njihovim boljim uspjehom. Suprotno tome, materijalna oskudica rezultira slabijim ulaganjem, ali i lošijim ishodima i uspjehom djece.

Druga skupina modela stavlja naglasak na odnos materijalne obiteljske situacije i kvalitete obiteljskih odnosa i postupaka prema djeci. Jedan od relevantnih teorijskih koncepata je model obiteljskog stresa. ${ }^{18}$ On se temelji na pretpostavci da financijski problemi, determinirani niskim prihodima, dugovima, onemogućavaju zadovoljavanje osnovnih obiteljskih potreba (hrana, odjeća, adekvatno stanovanje i sl.). Visok ekonomski pritisak rezultira stresom i popratnim

\footnotetext{
vement, employment and health, Family Matters, 93 (2013) 27-35.

${ }^{17}$ Usp. R. D. CONGER, M. B. DONNELLAN, An interactionist perspective on the socioeconomic context of human development, Annual Review of Psychology, 58 (2007) 175-199.

${ }^{18}$ Usp. R. D. CONGER, K. J. CONGER, M. J. MARTIN, Socioeconomic status, family processes, and individual development, Journal of Marriage and Family, 72 (2010) 3, 685-704.
} 
emocionalnim i mentalnim problemima roditelja, kao što su ljutnja, tjeskoba, depresija, a što često dovodi do lošijih odnosa među njima, učestalijih sukoba pa i razvoda braka. Sve navedeno utječe i na kvalitetu njihova roditeljstva, a što se u konačnici snažno reflektira neposredno i posredno na dječju prilagodbu.

Neki siromašni roditelji koji su iscrpljeni neimaštinom i borbom da osiguraju osnovne materijalne uvjete (ponekad rade i nekoliko slabo plaćenih poslova), neprimjereno reagiraju na potrebe djece, češće ih opažaju negativno i prakticiraju neadekvatne odgojne metode (zanemarivanje, kažnjavanje, zlostavljanje), ${ }^{19}$ a nisu u mogućnosti ulagati ni sredstva ni vrijeme u njihov napredak. Za razliku od njih, roditelji višeg socio-ekonomskog statusa, uz to što više ulažu u svoju djecu, prema njima pokazuju više topline i poštovanja, izbjegavaju fizičko kažnjavanje, više su uključeni i zainteresirani za njihove aktivnosti i uspjeh. ${ }^{20}$

Može se zaključiti da siromaštvo i loši obiteljski materijalni uvjeti utječu na školski uspjeh djece na dva načina. Ponajprije izravno, putem nedovoljne i neadekvatne prehrane i uvjeta stanovanja, prostora za učenje te nedostatka sredstava za nabavu knjiga i školskog pribora, instrukcija i ulaganja u aktivnosti koje olakšavaju postizanje uspjeha. Osobito je važan neizravan utjecaj putem kvalitete roditeljstva, odnosno nedovoljne osjetljivosti i odgovornosti roditelja za dijete, nedostataka psihosocijalne stimulacije i podrške. ${ }^{21}$

U navedenim modelima osobito je naglašena posredujuću ulogu roditeljskog stresa, a kad roditelji doživljavaju kroničan stres, velika je vjerojatnost da će stresu biti izložena i njihova djeca. ${ }^{22}$ A smatra se da je kroničan stres koji djeca doživljavaju, temeljni mehanizam koji povezuje siromaštvo i negativne obrazovne ishode. ${ }^{23}$

I recentna neurobiološka istraživanja bacaju novo svjetlo na uzroke školskih problema djece koja žive u siromaštvu. Hair i sur. su provjeravali je li odnos između siromaštva i lošijeg školskog uspjeha uvjetovan atipičnim razvojem mozga. ${ }^{24} \mathrm{U}$ istraživanju je sudjelovalo 389 djece i adolescenta od 4 do 22 godine iz SAD-a. Sudionici su bili praćeni, a snimanje magnetskom rezonancijom je provedeno tri puta u razmacima od dvije godine. Kod djece iz siromašnih obitelji utvrđen je atipični razvoj mozga u nekoliko područja (frontalnom i temporalnom režanju, te hipokampusu), a najizraženiji su problemi opaženi kod djece iz najsiromašnijih obitelji. Navedene regije mozga povezane su s procesima učenja, kao što je održavanje pažnje, planiranje i kognitivna fleksibilnost, a

\footnotetext{
${ }^{19}$ Usp. P. ENGLE, M. M. BLACK, The effect of poverty on child development and educational outcomes, Annals of the New York Academy of Sciences, 1136 (2008) 243-256.

${ }^{20}$ Usp. Conger, Donnellan, nav. dj.

${ }^{21}$ Usp. Engle, Black, nav. dj.; L. BERGER, C. PAXON, J. WALDFOGEL, Income and Child Development, Children and Youth Services Review, 31 (2009) 9, 978-989.

${ }^{22}$ Usp. Engle, Black, nav. dj.

${ }^{23}$ Usp. G. EVANS, P. KIM, Childhood poverty, chronic stress, self-regulation, and coping, Child Development Perspectives, 7 (2013) 1, 43-48, 44.

${ }^{24}$ Usp. N. L. HAIR i dr., Association of Child Poverty, Brain Development, and Academic Achievement, Pediatrics, 169 (2015) 9, 822-829.
} 
osjetljive su na utjecaje okoline i odgoja pa se stoga dječji potencijali za školski uspjeh umanjuju. Jensen, sumiranjem različitih novijih istraživanja, tome dodaje da se utvrđene razlike u mozgu siromašne djece mogu povezati i s deficitima u jezičnim vještinama, vizualno-prostornim sposobnostima, memoriji, kontroli, ali i inteligenciji. ${ }^{25}$

Dakle, siromašna se djeca u svome odrastanju suočavaju s povišenim razinama stresa, češće imaju iskustvo obiteljske nestabilnosti i neadekvatnog roditeljskog postupanja, pa i nasilja, doživljavaju manje podrške i kognitivne stimulacije u ranim, osjetljivim razvojnim razdobljima, a sve to pojedinačno ili interaktivno može doprinijeti neurobiološkim razlikama.

Na temelju ovog pregleda može se zaključiti da odrastanje u siromaštvu nepovoljno utječu na razvoj dječjih sposobnosti koje determiniraju njihov školski uspjeh.

\section{Učinci obiteljskih materijalnih nedaća na rani razvoj i uspjeh djece}

U literaturi se osobita pozornost pridaje utjecaju siromaštva i materijalnih obiteljskih poteškoća na dječji kognitivni razvoj i njihovu psihosocijalnu prilagodbu u prvim godinama života, stoga što je to rano razdoblje identificirano kao presudno za formiranje vještina i sposobnosti važnih za školsko postignuće. ${ }^{26}$ Ta povezanost potvrđena je i u empirijskim istraživanjima.

Na osnovu podataka koji su prikupljeni za MCS (Millennium Cohort Study) u Velikoj Britaniji, ispitivana je veza obiteljskih materijalnih poteškoća i ranih razvojnih ishoda. ${ }^{27} \mathrm{U}$ ispitivanju je sudjelovao 14.661 roditelj, a provedeno je $u$ dva navrata, kad su djeca imala 9 mjeseci i 3 godine. Rezultati pokazuju statistički značajne, korozivne učinke obiteljskih financijskih poteškoća na kognitivni razvoj i bihevioralnu prilagodbu te djece. Oni impliciraju da dugotrajna izloženost snažno negativno utječe na razvojne ishode.

Navedeni problemi se ponajprije očituju u procjeni spremnosti djece za školu, a pod kojom se podrazumijevaju razvijene sposobnosti (kognitivne, emocionalne, socijalne, motivacijske, tjelesne) i postizanje određenog stupnja funkcioniranja koji djetetu omogućava da primjereno odgovori na školske zahtjeve. ${ }^{28}$ To nije isključivo posljedica spontanog biološkog sazrijevanja, već u

\footnotetext{
${ }^{25}$ Usp. E. JENSEN, Teaching with Poverty in Mind. What Being Poor Does to Kids' Brains and What Schools Can Do About It, Alexandria, VA: Association for Supervision and Curriculum Development, 2009.

${ }^{26}$ Usp. Schoon i dr., nav. dj.; Šućur i dr., nav. dj.; Hair i dr., nav. dj.

${ }^{27}$ Usp. Schoon i dr., nav. dj.

${ }^{28}$ Usp. E. M. THOMAS, Readiness to learn at school among five-year-old children in Canada. Children and Youth Research Paper Series, Ottawa, Statistic Canada, 2006; M. ČUDINAOBRADOVIĆ, Spremnost za školu. Višestruko značenje pojma i njegova suvremena uporaba,
} 
tome značajnu ulogu imaju i uvjeti u kojima dijete živi. Relacijski i socijalno konstruktivistički teorijski modeli potenciraju važnost interakcije djeteta i njegove okoline, ${ }^{29}$ a osobito ističu utjecaj obitelji. Tako se navodi da djeca koja odrastaju u siromaštvu i materijalno nepovoljnim uvjetima ne dobivaju adekvatne poticaje i ne uče socijalne vještine koje bi ih pripremile za školu, te su kod njih opaženi kognitivni i bihevioralni nedostatci. ${ }^{30}$

$\mathrm{Na}$ temelju podataka iz nacionalnoga longitudinalnog istraživanja djece i mladih u Kanadi (NLSCY) opisani su obiteljski čimbenici povezani s mjerama pripravnosti za školu i spremnosti za učenje. ${ }^{31}$ Rezultati ovog istraživanja pokazuju da je obiteljski dohodak značajan prediktor spremnosti za školu. Utvrđeno je da je niži obiteljski dohodak i niža razina obrazovanja roditelja bila povezana sa slabije razvijenim vokabularom, komunikacijskim vještinama, računanjem, pozornosti i uključivanjem $u$ kooperativne igre s drugom djecom, odnosno socijalnim kompetencijama. Suprotno tome, djeca iz imućnijih obitelji čiji su roditelji imali više razine obrazovanja postigli su bolje rezultate na analiziranim varijablama.

U istraživanju UNICEF-a koje je provedeno u Hrvatskoj u kojem je sudjelovao 1621 roditelj djece rane dobi, ispitivane su i razlike u učestalosti poticajnih i podržavajućih, te nepoželjnih roditeljskih ponašanja s obzirom i na sociodemografska obilježja roditelja. ${ }^{32}$ Utvrđeno je da manje poželjne interakcije s roditeljima doživljavaju djeca čiji su roditelji nižeg socioekonomskog statusa i nižeg stupnja obrazovanja. A 14 \% roditelja šestogodišnjaka odgovorilo je da ni jednom u sedam dana prije provođenja istraživanja, nisu poticali ni radili na jačanju dječjih kognitivnih, grafomotoričkih i socio-emocionalnih sposobnosti. Dakle, sposobnosti koje čine osnovu spremnosti za školu. Uz to, petina šestogodišnjaka, prema samoiskazu ispitanih roditelja, doživljava tjelesno kažnjavanje na tjednoj osnovi, a ispitanici nižeg socioekonomskog statusa izvijestili su o višim raznima stresa. Utvrđeno je također da oni koji imaju više razine stresa imaju i manje poticajne i manje podržavajuće interakcije s djecom.

Iz ovog pregleda je razvidno da su mogući čimbenici koji u obiteljskom okruženu pridonose spremnosti za učenje socijalno-ekonomski status, interakcije roditelji-dijete i kognitivna stimulacija. Može se zaključiti da se kod djece koja odrastaju u siromaštvu nastaju problemi u razvoju jezičnih, komunikacijskih i socijalnih vještina, računanju i samokontroli. Dakle, u ključnim komponentama za postizanju ranog uspjeha i spremnosti djeteta za školu.

Nekoliko je mogućih razloga kojima se može objasniti štetan utjecaj odrastanja u siromaštvu i materijalno nepovoljnim uvjetima na rani razvoj djece i

\footnotetext{
Odgojne znanosti, 10 (2008) 2, 285-300.

${ }^{29}$ Usp. Čudina-Obradović, nav. dj.

${ }^{30}$ Usp. Ferguson, Bovaird, Müller, nav. dj.

${ }^{31}$ Usp. Thomas, nav. dj.

${ }^{32}$ Usp. N. PEĆNIK, Kako roditelji i zajednica brinu o djeci najmanje dobi u Hrvatskoj, Zagreb, Ured UNICEF-a za Hrvatsku, 2013.
} 
njihova postignuća. Ponajprije, to je razdoblje važno za razvoj mozga, odnosno formiranje strukture i funkcija koje će oblikovati kognitivne, emocionalne i socijalne ishode. U tom su razdoblju djeca najosjetljivija na poticaje iz okoline, izrazito otvorena za učenje. No djeca su tad podložna i štetnom utjecaju stresa, koji ima mjerljive učinke na strukturu mozga te je vjerojatno da će ostaviti dugotrajne posljedice za mentalno funkcioniranje. ${ }^{33} \mathrm{~S}$ druge strane, $\mathrm{u}$ ranom razdoblju života djece obiteljski kontekst ima dominantnu ulogu, ${ }^{34}$ a istraživanja impliciraju da su za razvoj dječjih potencijala neobično važne upravo interakcije s roditeljima. ${ }^{35}$ Izostanak pozitivnih interakcija i kognitivne stimulacije ostavlja posljedice na različite aspekte njihova razvoja, pa i na njihovu spremnost za školu.

Poznato je da je spremnost za školu polazna osnova za uspjeh u nastavku obrazovanja. Općenito, teško je polaziti iz negativne pozicije, a nepripremljenost za školu to svakako jest. Početni neuspjesi imaju tendenciju da se učvrste, ${ }^{36}$ a djeca se teško s njima sučeljavaju i teško mijenjaju sliku o sebi kao neuspješnim učenicima, što nerijetko rezultira niskim samopouzdanjem i samopoštovanjem, frustracijom, nezadovoljstvom, lošim odnosom prema školi i sl. Tako su ova djeca zbog materijalnih uvjeta u kojima žive, nerijetko ograničena već na početku svoga obrazovanja i teško nadoknađuju te zaostatke u postizanju i održavanju školskog uspjeha. Istraživanja pokazuju da razlike u mogućnostima koje postoje na početku školovanja imaju tendenciju da se produlje, te određuju njihov tijek školovanja i kasnijeg razvoja. ${ }^{37}$ Čini se da doživljaj siromaštva u ranom djetinjstvu snažnije utječe na školski uspjeh nego siromaštvo doživljeno u srednjem djetinjstvu ili adolescenciji. ${ }^{38}$

\section{Je li novac uistinu važan za školski uspjeh djece?}

Opravdano je očekivati da će višestruki nedostatci s kojima djeca slabijeg socioekonomskog statusa započinju školovanje otežavati njihov napredak, ugroziti njihova postignuća, ali i promijeniti njihov razvojni put. ${ }^{39}$ Ferguson i sur. su analizirali rezultate međunarodne PISA (Programme for International Student Assessment) studije o ocjenjivanju petnaestogodišnjaka u čitanju i matematici, koje je provedeno u 43 zemlje, a utvrđeno je da je niži socioekonomski obiteljski

\footnotetext{
${ }^{33}$ Usp. Hair i dr., nav. dj.; Šućur i dr., nav. dj.

${ }^{34}$ Usp. Duncan, Kalil, Ziol-Guest, nav. dj.

${ }^{35}$ Usp. Thomas, nav. dj.; Ferguson, Bovaird, Müller, nav. dj.; Engle, Black, nav. dj.; Pećnik, nav. dj.

${ }^{36}$ Usp. Bilić, Uzroci, posljedice...

${ }^{37}$ Usp. Schoon i dr., nav. dj.

${ }^{38}$ Usp. C. McDONALD, Children's lived experience of poverty. A review of the literature, Prepared by the ARACY Collaborative team undertaking the Children's Lived Experience of Poverty project, including. RMIT University, the NSW Commission for Children and Young People and the Benevolent Society, 2008.

${ }^{39}$ Usp. Engle, Black, nav. dj.; Schoon i dr., nav. dj.; Evans, Kim, nav. dj.
} 
status bio povezan i s nižim rezultatima djece. A razlike između skupina djece višeg i nižeg socioekonomskog statusa bile su velike i statistički značajne. ${ }^{40}$

U istraživanju koje se temelji na OECD - PISA međunarodnom ispitivanju u kojem je sudjelovalo 5.209 učenika iz Hrvatske, utvrđeno je da bolje rezultate iz prirodoslovlja postižu učenici iz obitelji s višim mjesečnim prihodima te oni čiji roditelji imaju završenu barem srednju školu. A učenici koji dolaze iz obitelji s prihodima manjim od $4.000 \mathrm{kn}$ postižu najlošije rezultate. ${ }^{41} \mathrm{Na}$ osnovu podataka prikupljenih za potrebe vanjskog vrednovanja, odnosno na populacijskim podacima (četvrti razred $\mathrm{N}=43.008$; osmi razred $\mathrm{N}=46.173$ ) ispitivalo se učinke obrazovanja roditelja na obrazovno postignuće učenika u Republici Hrvatskoj. ${ }^{42}$ Autori navode da su odabrali obrazovanje roditelja kao najstabilniju komponentu koja posredno ukazuje na SES i primanja. Rezultati dvosmjerne analize varijance ukazuju na izrazit efekt obrazovanja roditelja na obrazovno postignuće za obje skupine, a učenici s povoljnijom strukturom obrazovanja roditelja postižu bolji opći školski uspjeh i uspjeh iz hrvatskog jezika.

$\mathrm{Na}$ školski uspjeh učenika nesumnjivo utječu brojni čimbenici, a za potrebe ovog rada analizirat ćemo potencijalno rizične čimbenika koji se mogu povezati s materijalnim uvjetima u kojima djeca žive.

\subsection{Individualni čimbenici}

U prethodnom poglavlju je ukazano na povezanost uvjeta odrastanja s razvojem kognitivnih problema (pamćenjem, pažnjom, inteligencijom) za koje se smatra da imaju dominantnu ulogu u školskom postignuću. Neke studije pokazuju da djeca iz siromašnih obitelji češće imaju kognitivne probleme, a utvrđena je povezanost niskog socioekonomskog statusa i slabijega školskog uspjeha u različitim zemljama i na svim razinama obrazovanja. ${ }^{43}$ No odrastanje $u$ analiziranim uvjetima može se povezati sa štetnim učincima i na konativne (voljne) osobine, ponajprije upornost, ustrajnost. Upozorava se na nižu razinu samoučinkovitosti, ali i nižu motivaciju ove skupine djece. ${ }^{44} \mathrm{Su}-$ gerira se da okruženje siromaštva ne potiče učenje i uspjeh, a značajno utječe na negativno samopoštovanje djece koje doslovno ubija motivaciju. ${ }^{45}$ Stoga,

\footnotetext{
${ }^{40}$ Usp. Ferguson, Bovaird, Müller, nav. dj.

${ }^{41}$ Usp. M. GREGUROVIĆ, S. KUTI, Učinak socioekonomskog statusa na obrazovno postignuće učenika. Primjer PISA istraživanja, Hrvatska 2006, Revija za socijalnu politiku, 17 (2010) 2, 179-196.

${ }^{42}$ Usp. B. JOKIĆ, Z. RISTIĆ DEDIĆ, Razlike u školskom uspjehu učenika trećih i sedmih razreda osnovnih škola u Republici Hrvatskoj s obzirom na spol učenika i obrazovanje roditelja. Populacijska perspektiva, Revija za socijalnu politiku, 17 (2010) 3, 354-362.

${ }^{43}$ Engle, Black, nav. dj.

${ }^{44}$ Usp. W. T. SHANKS i dr., Assets and child well-being in economically developed countries, Children \& Youth Services Review, 32 (2010) 1488-1496.

${ }^{45}$ Usp. K. PELLINO, The effects of poverty on teaching and learning, (2007) www.teach-nology. com/tutorials/teaching/poverty/ (17.01.2016).
} 
neovisno o svojim sposobnostima, učenici koji odrastaju u takvom okruženju imaju tendenciju postavljati niže ciljeve, sami predviđaju niže ocjene prije nego završe zadatak, a češće su od svojih vršnjaka koji ne žive u takvim uvjetima demoralizirani. Čini se da visokostresno i nepoticajno životno okruženje određuje njihovu spremnost za učenje, ${ }^{46}$ odnosno da se u takvim okolnostima dječji potencijali za uspjeh smanjuju. ${ }^{47}$

Danas je sasvim jasno da i emocije igraju važnu ulogu u školskom uspjehu djece. Sumiranjem rezultata različitih istraživanja Jensen skreće pozornost na uočeno beznađe, bespomoćnost, povećane razine simptoma depresije kod ove skupine djece. ${ }^{48} \mathrm{~A}$ zbog problema sa samoregulacijom, siromašna djeca su često frustrirana i lako odustaju od zadataka, više je vjerojatno da će postati pasivni i nezainteresirani za školu. Uz to, djeca koja odrastaju u siromaštvu češće pokazuju neprimjerene emocionalne reakcije, manje empatije za tuđe probleme, što ometa njihove socijalne interakcije unutar razreda, a reflektira se i na njihove školske rezultate. ${ }^{49}$

\subsection{Obiteljski čimbenici}

Već smo spomenuli da obitelj može izravno i neizravno utjecati na školski uspjeh djece. ${ }^{50}$ Izravni učinci fokusiraju se na osiguravanje materijalnih uvjeta koji će olakšati postizanje uspjeha. Siromašna djeca često nemaju adekvatnu prehranu, žive u tamnim, vlažnim prostorima, bez osnovnih uvjeta, pribora, knjiga i mjesta za učenje. Roditelji im ne mogu osigurati potporu za učenje ili to čine uz velika odricanja, a to izravno utječe na njihov školski uspjeh. Za razliku od njih, bogatije obitelji mogu stvoriti takve uvjete i organizirati potporu za razvoj potencijala svoje djece. ${ }^{51}$

No smatra se da neekonomski čimbenici koji imaju neizravne učinke, mogu bolje objasniti odnos između obiteljskih varijabli i školskog uspjeha djece, ${ }^{52}$ a pri tome se naglasak stavlja na roditeljske interakcije i postupke..$^{53}$ Sukladno prethodno opisanim teorijskim modelima, financijski problemi utječu na loš odnos među roditeljima, što se odražava i na kvalitetu roditeljstava, pa je u njihovim interakcijama s djecom opaženo pomanjkanje topline i brižnosti,

\footnotetext{
${ }^{46}$ Usp. isto.

${ }^{47}$ Usp. Hair i dr., nav. dj.

${ }^{48}$ Usp. Jensen, $n a v$. $d j$.

${ }^{49}$ Usp. isto.

${ }^{50}$ Usp. Shanks i dr., nav. dj.; S. ŠIMIĆ ŠAŠIĆ, M. KLARIN, A. PROROKOVIĆ, Socioekonomske prilike obitelji i kvaliteta obiteljske interakcije kao prediktori školskog uspjeha srednjoškolaca u Hrvatskoj, Bosni i Hercegovini i Makedoniji, Ljetopis socijalnog rada, 18 (2011) 1, 31-62.

${ }^{51}$ Usp. T. RIDGE, Living with Poverty. A Review of the Literature on Children's and Families' Experiences of Poverty, Research Report No. 594, Department for Work and Pensions, Norwich, HMSO, 2009; Shanks i dr., nav. dj.

${ }^{52}$ Usp. Shanks i dr., nav. dj.

${ }^{53}$ Usp. Šimić Šašić, Klarin, Proroković, nav. dj.
} 
smanjena osjetljivost, ali i neprimjereno, grubo reagiranje, češća kažnjavanja, pa i zlostavljanja. ${ }^{54}$ Smatra se da kvaliteta interakcija između roditelja i djece snažnije utječe na dječji uspjeh nego dohodak. ${ }^{55}$

Kad se govori o roditeljskim postupcima važnim za uspjeh, u novijim studijama se ističe roditeljska uključenost, odnosno pružanje pomoći u učenju kod kuće i u izradi domaćih zadataka (bihevioralna uključenost), ali i poticanje aktivnosti i iskustava (kognitivna uključenost), kao i stavovi i očekivanja roditelja (osobna uključenost). ${ }^{56}$ Siromašna djeca su često lišena roditeljske pomoći, ${ }^{57}$ ponajprije stoga što su njihovi roditelji najčešće i lošije obrazovani, pa im uz najbolju volju ne mogu pomoći. Uz nedostatnu instrumentalnu i informacijsku potporu, roditelji nižeg stupnja obrazovanja djeci pružaju i manje emocionalne i socijalne podrške, ${ }^{58}$ a obično im ne prenose ni stavove i uvjerenja o važnosti školovanja. ${ }^{59}$ Općenito, siromašni roditelji pokazuju manje kontrole i vode manje brige o obrazovanju svoje djece, najvjerojatnije zbog preopterećenosti egzistencijalnim problemima. Istraživanja potvrđuju da slabije školsko postignuće imaju siromašna djeca čiji roditelji imaju niži stupanj obrazovanja. ${ }^{60}$

Suprotno tome, bogatiji roditelji koji su češće i bolje obrazovani osobno pomažu svojoj djeci ili im organiziraju pomoć (instrukcije), znaju bolje voditi djecu kroz obrazovni proces, ${ }^{61}$ više nadziru njihove aktivnosti, ${ }^{62}$ više se angažiraju oko školskih zadataka, te potiču obrazovni uspjeh. ${ }^{63} \mathrm{Uz}$ to, oni služe i kao modeli za djecu, prenose im svoje težnje i očekivanja te razvijaju djetetova ponašanja potrebna za ostvarivanje ciljeva obrazovanja. ${ }^{64}$

Može se zaključiti da je za postizanje školskog uspjeha djece važan roditeljski angažman koji uključuje niz relevantnih ponašanja kao što je kognitivna stimulacija, uključenost $u$ izvršavanje školskih zadaća, nadgledanje i praćenje napretka, pomoć u određivanju strategija učenja i formiranje ustrajnosti kao temelja za gradnju uspjeha. Pri tome se ne smije zanemariti ni važnost podrške, roditeljskih očekivanja i težnji te poticanje obrazovnih i profesionalnih

${ }^{54}$ Usp. Conger, Donnellan, nav. dj.; Engle, Black, nav. dj.; R. S. MISTRY i dr., Family economic stress and academic well-being among Chinese-American youth. The influence of adolescents' perceptions of economic strain, Journal of family psychology, 23 (2009) 3, 279-290; Conger, Conger, Martin, nav. dj.

${ }^{55}$ Usp. K. BULLOCK i dr., Educational relationships in out-of-school-time activities. Are children in poverty missing out again?, Education, Citizenship and Social Justice, 5 (2010) 2, 103116.

${ }^{56}$ Usp. Šimić Šašić, Klarin, Proroković, nav. dj.

${ }^{57}$ Usp. D. HIRSCH, Experiences of poverty and educational advantage, York, JRF, 2007.

${ }^{58}$ Usp. I. KATZ i dr., The Relationship Between Parenting and Poverty, York, JRF, 2007.

${ }^{59}$ Usp. Šimić Šašić, Klarin, Proroković, nav. dj.

${ }^{60}$ Usp. Jokić, Ristić Dedić, nav. dj.; Gregurović, Kuti, nav. dj.; McCoy i dr., nav. dj.; Ratcliffe, nav. dj.

${ }^{61}$ Usp. T. MATKOVIĆ, Obrazovanje roditelja, materijalni status i rano napuštanje školovanja u Hrvatskoj. Trendovi u proteklom desetljeću, Društvena istraživanja, 19 (2010) 4-5, 643-667.

${ }^{62}$ Usp. Hirsch, nav. dj.

${ }^{63}$ Usp. Gregurović, Kuti, nav. dj.

${ }^{64}$ Usp. Shanks i dr., nav. dj. 
aspiracija i planiranja budućnosti. Dakle, uspjeh traži relevantno ponašanje i roditelja i djece.

\section{3. Školski čimbenici}

Učenici koji dolaze iz obitelji nižeg socioekonomskog statusa, imaju poteškoća u funkcioniranju u školi i ostvarivanju školskih ciljeva.

Ponajprije, oni imaju slične potrebe kao i njihovi vršnjaci koji dolaze iz imućnijih obitelji, s njima se neprestano uspoređuju. Kad su rezultati socijalne komparacije negativni, oni se osjećaju loše, a to snažno utječe na njihov osjećaj osobne vrijednosti. ${ }^{65}$ Zbog svih tih razloga nerijetko od svojih vršnjaka doživljavaju ismijavanje omalovažavanje, izrugivanje, vrijeđanje, isključivanje iz školskih aktivnosti pa i nasilje. Reakcije djece na takve situacije mogu biti dvostruke. Kod jednih, zbog percipirane nepravde, prevladaju osjećaji ljutnje pa su skloni reagirati i agresivno. Kod drugih prevladaju osjećaji bespomoćnosti, beznadnosti, tuge, tjeskobe, povlače se i postaju očajni, a stoga češće i žrtve fizičkih i ne-fizičkih oblika nasilja. ${ }^{66} \mathrm{U}$ školi se ne osjećaju sigurno ni ugodno. Istraživanja pokazuju da su materijalno deprivirana djeca najčešće žrtve vršnjačkog nasilja. ${ }^{67} \mathrm{~A}$ odnosi u kojima uče imaju značajan utjecaj na njihovo postignuće. $^{68}$

Ono što doživljavaju u školi vezano uz uvjete u kojima odrastaju, odražava se i na druge domene školskog funkcioniranja, a utječe na njihov uspjeh. Osobito se ističe negativan utjecaj na školski angažman, na slabiji osjećaj pripadnosti školi, općenito na stavove o školi i obrazovanju, te na obrazovne aspiracija ${ }^{69}$ Nikako ne treba zanemariti kumulativne učinke svih navedenih problema. Čini se da su siromašna djece u školi često u nepovoljnom položaju, odnosno da u školskom funkcioniranju imaju ozbiljne probleme koji im dodatno otežavaju postizanje uspjeha, a što se odražava i na nastavak obrazovanja.

\section{Siromaštvo i ishodi obrazovanja}

Iako obrazovanje vide kao put do boljeg života ili kao jedan od mehanizama za bijeg od siromaštva, ${ }^{70}$ djeca koja dolaze iz obitelji nižeg socioekonomskog statusa zbog kombinacije prethodno postignutog lošeg uspjeha i materijalnih

\footnotetext{
${ }^{65}$ Usp. Ridge, nav. dj.

${ }^{66}$ Usp. V. BILIĆ, The role of socioeconomic differences and material deprivation in peer violence, Epiphany. Journal of Transdisciplinary Studies, 8 (2015) 2, 177-202.

${ }^{67}$ Usp. Ridge, nav. dj.; Bilić, The role of socioeconomic...

${ }^{68}$ Usp. Bullock i dr., nav. dj.

${ }^{69}$ Usp. Hirsch, nav. dj.; McDonald, nav. dj.; Mistry i dr., nav. dj.

${ }^{70}$ Usp. Engle, Black, nav. dj.
} 
(ne)mogućnosti, najčešće su zabrinuta za budućnost i vjeruju da teško mogu ostvariti svoje težnje i snove, te da je završetak obrazovanja cilj koji teško mogu doseći. $^{71}$

Socijalne nejednakosti snažno se očituju na prijelazu iz obveznog u srednje obrazovanje, ${ }^{72}$ a najveća nejednakost se opaža u pristupu i završavanju visokog obrazovanja. ${ }^{73}$ Nakon završene osnovne škole velik broj djece zbog troškova (putovanja, stanovanja i sl.), ali i lošijeg uspjeha, nije u mogućnosti otići u školu po svome izboru ${ }^{74}$ ili upisuju programe koje vremenski kraće traju, pa su to dodatni elementi koji ih mogu demotivirati. Zbog lošijeg materijalnog statusa djeca postižu slabiji školski uspjeh (primarni efekt), ali kad je njihov školski uspjeh podjednak kao kod njihovih kolega iz imućnijih obitelji, zbog razlika u resursima i ambicijama njihovih roditelja manja je vjerojatnost da će upisati viši stupanj obrazovanja (sekundarni efekt). ${ }^{75} \mathrm{Kad}$ nastave školovanje djeca koja žive u siromaštvu sklonija su izostajanju $s$ nastave ${ }^{76}$ i u većem su riziku za napuštanje škole. ${ }^{77}$ Čak polovica učenika koji napuštaju školu odrasla je u obiteljima s niskim prihodima. ${ }^{78}$ Matković je ispitivao povezanost niske razine roditeljskog obrazovanja i prihoda kućanstva s povećanim rizikom napuštanja školovanja njihove djece. ${ }^{79}$ Rezultati pokazuju da je rizik ranog napuštanja školovanja u Hrvatskoj veći što je razina roditeljskog obrazovanja niža, a najveći je rizik za djecu koja odrastaju u najsiromašnijim kućanstvima. Bijeg iz siromaštva vjerojatniji je za one učenike koji ostaju u sustavu obrazovanja nakon šesnaeste godine. ${ }^{80}$ Neki autori upozoravaju na izravne učinke prihoda na godine školovanja, odnosno da djeca koja žive u siromaštvu češće završavaju niži stupanj obrazovanja, a manja je vjerojatnost da će završiti fakultet ${ }^{81}$ Ovi obrasci se nerijetko nastavljaju i u odrasloj dobi, niže obrazovno postignuće povezuje se $\mathrm{s}$ manjim šansama za trajno zaposlenje mladih te s uspjehom na radnom mjestu u odrasloj dobi, a reflektira se i na niske prihode.$^{82}$ Nameće se zaključak da su djeca, koja su dugo izložene siromaštvu, zakinuta za uspjeh i

\footnotetext{
${ }^{71}$ Usp. McDonald, nav. dj.; Ridge, nav. dj.

${ }^{72}$ Usp. Matković, nav. dj.; Gregurović, Kuti, nav. dj.

${ }^{73}$ Usp. S. PUZIĆ, K. DOOLAN, D. DOLENEC, Socijalna dimenzija »Bolonjskog procesa « i (ne) jednakost šansi za visoko obrazovanje. Neka hrvatska iskustva, Sociologija sela, 44 (2006) 2-3, 243-260.

${ }^{74}$ Usp. McDonald, nav. dj.

${ }^{75}$ Usp. Matković, nav. dj.

${ }^{76}$ Usp. Bullock i dr., nav. dj.

${ }^{77}$ Engle, Black, nav. dj.

${ }^{78}$ Usp. Ferguson, Bovaird, Müller, nav. dj.

${ }^{79}$ Usp. Matković, nav. dj.

${ }^{80}$ Usp. Bullock i dr., nav. dj.

${ }^{81}$ Usp. Shanks i dr., nav. dj.; Ratcliffe, nav. dj.; Hair i dr., nav. dj.

${ }^{82}$ Usp. E. KNUDSEN i dr., Economic, neurobiological, and behavioral perspectives on building America's future workforce, Proceedings of the National Academy of Sciences, 103 (2006) 10155-10162; Ratcliffe, nav. dj.; Hair i dr., nav. dj.
} 
zapošljavanje, odnosno da odrastanje u siromaštvu određuje njihov nepovoljan položaj i tijekom odrasle dobi.

Odnos siromaštva i školskog uspjeha prenosi se s jedne generacije na drugu, a uklanjanje takvog ciklusa važan je dio borbe protiv njihovih dugoročnih učinaka, nejednakosti i nepravde..$^{83}$

\section{Zaključci i ključni prijedlozi}

Siromaštvo i niski socioekonomski status nisu najvažniji ni jedini uzroci školskog neuspjeha, jer na njega utječe niz čimbenika u međusobnom suodnosu. Budući da je siromaštvom pogođeno sve više djece nužno je ukazivati i na njegove moguće doprinose njihovim školskim i životnim ishodima. Analiziranje i bolje razumijevanje negativnih utjecaja siromaštva u funkciji je identificiranja mogućih zaštitnih mehanizama i procesa koji mogu olakšati djeci da razviju svoje potencijale i poboljšaju životne šanse.

Školski uspjeh učenika koji žive u siromaštvu nije samo problem škole. Stoga je potrebno razviti strategije za davanje višestruke podrške ugroženoj djeci na različitim razinama, vodeći računa o različitim aspektima života u kojima djeca odrastaju.

Važnu ulogu u tome imaju političke odluke, a neke studije sugeriraju da se učinci siromaštva najučinkovitije mogu smanjiti povećavanjem obiteljskih prihoda. ${ }^{84}$ Promjene dječjeg doplatka u Kanadi iskorištene su u jednoj studiji kako bi se ispitao utjecaj obiteljskih prihoda na dječju dobrobit. ${ }^{85}$ Utvrđeno je da je povećanje dječjeg doplatka dovelo do poboljšanja školskih rezultata siromašne djece. Utvrđena je statistički značajna pozitivna korelacija s uspjehom iz matematike i čitanja, kao i pozitivni učinci na fizičko zdravlje dječaka i mentalno zdravlje djevojčica. Čini se da ovaj problem ne može biti riješen samo jednokratnom socijalnom mjerom, ${ }^{86}$ nego on zahtijeva sustavan pristup i konkretnu pomoć.

Odgojno-obrazovne ustanove mogu utjecati na razvoj i uspjeh djece unatoč nepovoljnim uvjetima u kojim oni odrastaju. ${ }^{87} \mathrm{U}$ ovom radu je više puta istaknut snažan utjecaj nepovoljnih materijalnih uvjeta i s njima povezanih negativnih čimbenika u ranom razdoblju života djeteta, pa su stoga i važne rane intervencije. Njihov temeljni cilj je osiguravanje podrške takvoj djeci i razvoj vještina koje im nedostaju, odnosno poticanje intelektualnog i socio-emoci-

\footnotetext{
${ }^{83}$ Usp. Hirsch, nav. dj.

${ }^{84}$ Usp. Ferguson, Bovaird, Müller, nav. dj.

${ }^{85}$ Usp. K. MILLIGAN, M. STABILE, Do child tax benefits affect the well-being of children? Evidence from Canadian Child Benefit expansions, NBER Working Paper No. 14264, National Bureau of Economic Research; Cambridge, MA, 2008.

${ }^{86}$ Usp. Bullock i dr., nav. dj.

${ }^{87}$ Usp. Ferguson, Bovaird, Müller, nav. dj.; Thomas, nav. dj.
} 
onalnog razvoja i bolje pripremljenosti za školu, a što je temelj za postizanje uspjeha. U literaturi se navode primjere uspješnih ranih intervencija, ${ }^{88}$ a kod djece koja su u njima sudjelovala nakon završetka programa utvrđeni su bolji rezultati na testovima kognitivnih sposobnosti, bolji opći školski uspjeh te uspjeh u čitanju i matematici. Polaznici su završavali više godina obrazovanja i bilo je vjerojatnije da će upisati fakultet.

Budući da je siromaštvo stigmatiziran položaj o kojem i roditelji i učenici nerado govore, nerijetko izostane i pravovremena pomoć. Stoga je važno znati da i kasne intervencije ${ }^{89}$ mogu imati pozitivne učinke. Preporučljivo je, u suradnji s lokalnom zajednicom, organizirati konkretnu financijsku pomoć (stipendije, prijevoz i sl.) i pomoć za učenje. Siromašna djeca koja su koristila ovakve programe u većem su postotku završavala srednju školu, a velik ih je broj nastavljao školovanje i na visokim učilištima.

No da bi bili uspješni programi i rane i kasne intervencije moraju biti prilagođeni potrebama svakog djeteta te obvezno moraju uključiti roditelje. Uz konkretnu pomoć i osnaživanje roditelja, smanjenje negativnih učinaka siromaštva uključuje i edukaciju roditelja, odnosno proširivanje znanja o kvalitetnom roditeljskom odgojnom postupanju i komunikaciji. A kad je riječ o postizanju uspjeha potrebno je da roditelji osvijeste važnost njihove uključenosti i podrške.

U samoj školi tri jake relacijske sile doprinose uspjehu siromašne djece, a to je ponajprije siguran i pouzdan odnos s učiteljima, jačanje vršnjačkih veza te potraga za osobnom važnošću i društvenim statusom. ${ }^{90}$ Važna pomoć učitelja siromašnoj djeci, uz razumijevanje njihove pozicije i davanje podrške, jest poticanje otpornosti, konativnih komponenti i motivacije za učenje, objašnjavanje smisla učenja, pomoći u stvaranju ciljeva te kreiranju planova za učenje i uspjeh..$^{91}$ Ne manje važna zadaća učitelja jest i pomoć u stvaranju pozitivnih odnosa s vršnjacima i kreiranje razrednog ozračja u kojem će se i ova skupina djece osjećati dobrodošla i prihvaćena.

Nažalost, siromašna djeca su u obrazovnom sustavu nerijetko zanemarena. ${ }^{92} \mathrm{Ne}$ smanjuju se obrazovne nejednakosti, među učenicima su sve izraženije razlike s obzirom na njihov materijalni status i obrazovanje roditelja. ${ }^{93}$ Stoga je zaključno potrebno podsjetiti da je pravo na obrazovanje temeljno dječje pravo, a zadaća je svih da uklone prepreke uzrokovane socijalnim razlikama i da pomognu djeci u ostvarivanju njihovih potencijala, postizanju školskih i životnih uspjeha. I to ne samo deklarativno, već da im i praktično osiguraju jednake šanse za pristup visokom obrazovanju.

\footnotetext{
${ }^{88}$ Usp. Ferguson, Bovaird, Müller, nav. dj; vidi Chicago Child Parent Center.

${ }^{89}$ Usp. Ferguson, Bovaird, Müller, nav. dj.

${ }^{90}$ Usp. Jensen, nav. dj.

${ }^{91}$ Usp. Pellino, nav. $d j$.

${ }^{92}$ Usp. Hirsch, nav. dj.

${ }^{93}$ Usp. Jokić, Ristić Dedić, nav. dj.
} 


\section{Vesna Bilić*}

School achievement of children and young people who grow up in poverty and materially unfavourable conditions

\section{Summary}

Since poverty has been striking an increasing number of children and young people, it is necessary to indicate its possible effects on their school and life outcomes. Therefore, based on literature, this paper focuses on analysing factors of risk and processes which explain how growing up in poverty and material deprivation directly and indirectly affects school performance and educational outcomes of children. The paper points to negative effects in the early period of children's lives which is crucial in forming skills and abilities that are important for further academic achievement. Multiple defects they start their education with endanger their progress and success at all levels of education (early, school and graduate). A combination of poverty and low school achievement is often the reason for leaving school or completing a lower level of education and is also associated with lower chances for employment and opportunities for leaving the cycle of poverty. Finally, the paper presents suggestions for developing strategies, early and later interventions and providing multiple supports to families and children in realizing their potential, and achieving success, in both school and life.

Key words: poverty, socioeconomic status (SES), material deprivation, school achievement.

(na engl. prev. Ivona Pale)

\footnotetext{
* Vesna Bilić, PhD, Associate Professor, Department of Pedagogy, Faculty of Teacher Education, University of Zagreb, Address: Savska 77, HR-10000 Zagreb, Croatia; E-Mail: vesna.bilic@ufzg. hr.
} 